\title{
Design Methodology for the Selection of the Best Alternative of Industrial Machine Maintenance for Time Reduction*
}

\section{Metodología de Diseño para la Selección de la Mejor Alternativa en Reducción de Tiempos en el Mantenimiento de Maquinaria Industrial}

\author{
DOI: http://dx.doi.org/10.17981/ingecuc.11.2.2015.02
}

Research Article - Reception Date: December 09, 2014 - Acceptance Date: September 23, 2015

Wilmer Velilla Díaz

Master in Mechanic Engineering, Universidad Autónoma del Caribe, Barranquilla (Colombia). wvelilla@uac.edu.co

\section{Argemiro Palencia Díaz}

Master in Mechanic Engineering, Universidad Autónoma del Caribe, Barranquilla (Colombia). apalencia@uac.edu.co

To reference this paper:

W. Velilla Díaz, and A. Palencia Díaz, "Design Methodology for the Selection of the Best Alternative of Industrial Machine Maintenance for Time Reduction," INGE CUC, vol. 11, no. 2, pp. 18-26, 2015. DOI: http://dx.doi.org/10.17981/ ingecuc.11.2.2015.02

\begin{abstract}
This paper poses the application of a design methodology intended to improve a company's efficiency in maintenance processes in terms of time reduction. As the procedure involved altering the machine, the company needed to analyze several options due to the high investment required for all the possible modifications. For this reason, the company requested from the University a decision matrix. To accomplish this objective, a study to determine maintenance times was conducted and a critical stage during die dismantlement and assembly was identified. Based on this information, the decision matrix was elaborated. The best alternative was to replace mechanical guides for pneumatic guides. This option exceeded in $2 \%$ the second alternative and in $24 \%$ the last. The company succeeded in making a decision based on goal achievement and still today continues using decision matrixes for any adjustment in their processes.
\end{abstract}

Keywords - Design Methodology, Metric Matrix, Weighting Function, Hierarchical List of Objectives, Selection of Alternatives
Resumen- Este artículo describe la implementación de una metodología de diseño para una empresa que necesitaba modificar una máquina con el objetivo de reducir sus tiempos de mantenimiento. La decisión no era fácil, dada la alta inversión requerida para todas las posibles modificaciones. La empresa se acercó a la Universidad y solicitó el desarrollo de una matriz de decisión. Se hizo un estudio de los tiempos de mantenimiento y se identificó el punto crítico en el proceso de montaje y desmontaje del troquel de la máquina. Sobre este proceso se desarrolló la matriz de selección y se decidió el cambio de guías neumáticas, opción que superó en un $2 \%$ a la alternativa más cercana y en un $24 \%$ la más lejana. La empresa logró tomar una decisión basada en el cumplimiento de objetivos y hoy en día sigue realizando matrices de decisión para modificaciones en sus procesos.

Palabras Clave- Metodologías de Diseño, Matriz Métrica, Ponderación de Funciones, Objetivos Jerarquizados, Selección de Alternativas

\footnotetext{
* Research article derived from the research project: "Identificación de las Oportunidades de Mejoras Durante el Proceso del Cambio de Troquel para una Máquina Rescroll”. Funded by Universidad Autónoma del Caribe. Starting Date: May, 2010. Compleition Date: December, 2014.
} 


\section{INTRODUCTION}

Large-scale industries aim at managing time efficiently; machine tool stops for maintenance, adjustments, and replacements are taken very seriously [1]. In this project, a company manifested to the University its intention of implementing a strategy to cut die replacement time since it was identified as one of the most influencing factors for late delivery of production to customers.

For this research, a multi-alternative study of different proposals was carried through in order to assess these options regarding the company's needs. The alternatives were suggested by operators and engineers, as well as by the external advisory board. Weighted values for the desired conditions in terms of time management improvement during die replacement procedures were established. Criteria like problem identification, real necessity or list of weighted objectives statement, and effectiveness assurance [2], [3] were fundamental in order to determine the appropriate attributes to satisfy the corresponding needs. This project fosters synergy in university-enterprise collaborative work because companies develop confidence towards scientific institutions. By assessing the operators' suggestions, they became more committed to the process because they felt they were part of the process. This was an enriching experience for both, the university and the company, so the latter decided to develop more processes of this kind. Design methodologies aim at providing the most suitable solution to any problem and including the different agents and components within a productive process and value chain, thus, they are being implemented by companies in the city of Barranquilla, Colombia [4], [5].

\section{Methodology}

The method implemented in this project is presented in Fig. 1. This was the first approach with the com- pany, which expressed its interest in a user-friendly method for operators to implement in different equipment. In order to achieve the adequate method and guarantee that operators receive proper training, Terrence's theoretical foundations were applied as a strategy of design-oriented learning [6].

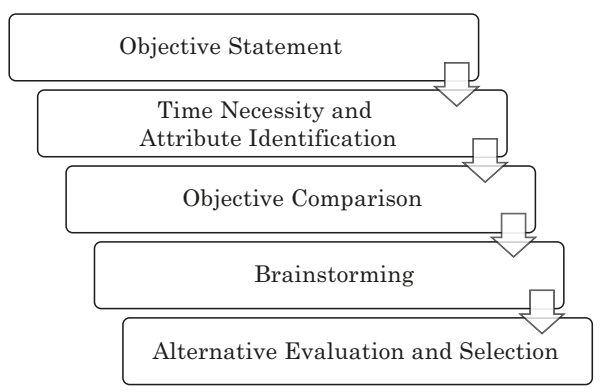

Fig. 1. Method Applied. Source: Authors

\section{III.OBjective Statement}

Selecting the best alternative to reduce die replacement time in the machine for a $1 / 4$ gallon container lid, ring and 603 steel bottom.

\section{Needs And Attribute Identification}

Engineering and goal-oriented needs are identified in this stage. They are suggested by the university team in regard to the factors observed during the process. These objectives, in turn, are verified by the company which approves them as being suitable to fulfill the best alternative choice for cost reduction [7].

The hierarchical list of objectives is presented in Table I. Additionally, the company has defined the level of relevance for each one; importance is established based on their priorities and taking into account the operator's suggestions of the die cutting machine.

Table I. Hierarchical List of ObJectives

\begin{tabular}{|c|c|c|c|}
\hline 1. Costs & 2. DESIGN & 3. LOGISTICS & 4. ENVIRONMENT \\
\hline $\begin{array}{l}\text { 1.1 Low investment in the system' } \\
\text { installation and setting up } \\
\text { infrastructure }\end{array}$ & $\begin{array}{l}2.1 \text { Compact } \\
\text { and modular } \\
\text { replacement } \\
\text { system }\end{array}$ & $\begin{array}{l}\text { 3.1 Fast assembly and } \\
\text { dismantling }\end{array}$ & 4.1 Eco-friendly \\
\hline $\begin{array}{l}\text { 1.2 User-friendly and inexpensive } \\
\text { operation }\end{array}$ & $\begin{array}{l}\text { 2.2 Minimal manual } \\
\text { intervention }\end{array}$ & 3.2 Easy installation & \multirow{4}{*}{ 4.2 Low noise levels } \\
\hline 1.3 Easy and low-cost maintenance & \multirow{3}{*}{ 2.3 Safe handling } & $\begin{array}{l}\text { 3.3 Safe and agile displacement } \\
\text { from storage site }\end{array}$ & \\
\hline 1.4 Low assembly costs & & \multirow{2}{*}{$\begin{array}{l}\text { 3.4 Procedures with likelihood } \\
\text { of a repetition }\end{array}$} & \\
\hline 1.5 Affordable and easy-to-find spare parts & & & \\
\hline
\end{tabular}




\section{Weighted Objectives}

The estimation method of weighted objectives of first and second levels is posed in Table II and Table III. This hierarchy allows establishing priorities so people in charge of evaluating the alternatives avoid digress in irrelevant objectives [8]. Table IV sets forth an evaluation scale for the company's valuation. Table V puts forward the method for achieving the selected matrix valuation.

Tables VI, VII, VIII, IX, and X present the objectives with the company's weighting values.

Table II. Estimation Method of Weighted Objectives - First Level

\begin{tabular}{|c|c|c|c|c|c|c|}
\hline Factors to be evaluated & Objective 1 & Objective 2 & $\ldots$ & Objective $\mathbf{n}$ & Total & Weight \\
\hline Objective 1 & VO11 & VO12 & $\ldots$ & VO1n & $\sum_{j=1}^{n} V_{1 j}$ & $\begin{array}{l}n \\
\sum_{j=1} \mathrm{VO} 1 \mathrm{j} \\
\mathrm{j}=\mathrm{P} 1 \\
\text { Wtotal }\end{array}$ \\
\hline Objective 2 & VO21 & VO22 & $\ldots$ & VO2n & $\sum_{j=1}^{n} \mathrm{VO} 2 \mathrm{j}$ & $\begin{array}{l}\mathrm{n} \\
\sum \mathrm{VO} 2 \mathrm{j} \\
\mathrm{j}=1=\mathrm{P} 2 \\
\text { Wtotal }\end{array}$ \\
\hline$\vdots$ & $\vdots$ & $\vdots$ & $\ldots$ & $\vdots$ & $\vdots$ & $\vdots$ \\
\hline Objective $\mathbf{n}$ & VOn1 & VOn2 & $\ldots$ & VOnn & $\sum_{j=1}^{n}$ VOnj & $\begin{array}{l}\mathrm{n} \\
\sum_{\mathrm{j}=1=\mathrm{VOnj}} \\
\text { Wtotal }\end{array}$ \\
\hline $\begin{array}{l}\text { Total value for first level objectives } \\
(\mathrm{VO}=\text { Value of Objective) }\end{array}$ & & & & & $\sum_{i=1}^{n}$ VOij=Wtotal & \\
\hline
\end{tabular}

Source: Authors

Table III. Estimation Method of Weighted Objectives - Second Level

\begin{tabular}{|c|c|c|c|c|c|c|c|}
\hline $\begin{array}{c}\text { Factors to be } \\
\text { evaluated }\end{array}$ & $\begin{array}{c}\text { Objective } \\
1.1\end{array}$ & $\begin{array}{c}\text { Objective } \\
1.2\end{array}$ & $\cdots$ & $\begin{array}{c}\text { Objective } \\
\text { 1.m }\end{array}$ & Total & $\begin{array}{c}\text { Relative } \\
\text { weight (RW) }\end{array}$ & $\begin{array}{c}\text { Absolute } \\
\text { weight (W) }\end{array}$ \\
\hline Objective 1.1 & CV11 & CV12 & $\cdots$ & CV1m & $\sum_{j=1}^{m}$ & $\begin{array}{l}\mathrm{m} \\
\sum_{\mathrm{j}=1=\mathrm{CV} 1 \mathrm{j}} \\
\text { Wstotal } 1.1\end{array}$ & RW1.1*P1=W1 \\
\hline Objective 1.2 & CV21 & CV22 & $\ldots$ & CV2m & $\sum_{j=1}^{m} \mathrm{CV} 2 \mathrm{j}$ & $\begin{array}{l}\mathrm{m} \\
\sum_{\mathrm{j}} \mathrm{CV} 2 \mathrm{j} \\
\text { Wstotal }\end{array}$ & $\mathrm{RW} 1.2 * \mathrm{P} 1=\mathrm{W} 2$ \\
\hline$\vdots$ & $\vdots$ & $\vdots$ & $\ldots$ & $\vdots$ & $\vdots$ & $\vdots$ & $\vdots$ \\
\hline Objective 1.m & $\mathrm{CVm} 1$ & $\mathrm{CVm} 2$ & $\ldots$ & CVmm & $\sum_{j=1}^{m}$ & $\begin{array}{l}\mathrm{m} \\
\sum_{\mathrm{j}=1=\mathrm{CVnj}} \\
\text { Wstotal }\end{array}$ & $\mathrm{RW} 1 . \mathrm{m} * \mathrm{P} 1=\mathrm{Wm}$ \\
\hline \multicolumn{5}{|c|}{$\begin{array}{l}\text { Criterion value of second level objectives of Objective } 1 \\
(\mathrm{CV}=\text { Criterion Value })\end{array}$} & $\sum_{\mathrm{i}=1}^{\mathrm{m}} \mathrm{CVij}=$ Wstotal & & \\
\hline
\end{tabular}


Table IV. Evaluation Scale

\author{
EVALUATION SCALE: \\ 1-Much Less Important \\ 3- Less Important \\ 5- Equally Important \\ 7- More Important \\ 10- Much More Important
}

\title{
Source: Authors
}

Table V. Estimation Method of the Alternative Selection

\begin{tabular}{|c|c|c|c|c|c|c|c|}
\hline & & & \multicolumn{5}{|c|}{ Alternativas } \\
\hline $\begin{array}{c}\text { First Level } \\
\text { Objetive }\end{array}$ & $\begin{array}{l}\text { Second Level } \\
\text { Objetive }\end{array}$ & $\begin{array}{l}\text { Weighted Second } \\
\text { Level Obejtive }\end{array}$ & Altenative 1 & $\ldots$ & Altenative 1 & & Altenative $\mathrm{m}$ \\
\hline \multirow{4}{*}{ - } & 1.1 & W1 & V11 & & $\mathrm{V} 1 \mathrm{j}$ & & $\mathrm{V} 1 \mathrm{~m}$ \\
\hline & 1.2 & W2 & V21 & & $\mathrm{V} 2$ & & $\mathrm{~V} 2 \mathrm{~m}$ \\
\hline & 1.3 & W3 & V31 & & $\mathrm{V} 3 \mathrm{j}$ & & $\mathrm{V} 3 \mathrm{~m}$ \\
\hline & 1.4 & W4 & V41 & & $\mathrm{V} 4 \mathrm{j}$ & & $\mathrm{V} 4 \mathrm{~m}$ \\
\hline \multirow{4}{*}{$\begin{array}{l}\infty \\
0 \\
0 \\
.00 \\
\frac{0}{0} \\
0\end{array}$} & 2.1 & W5 & V51 & & V5j & & V5m \\
\hline & 2.2 & W6 & V61 & & $\mathrm{V} 6 \mathrm{j}$ & & $\mathrm{V} 6 \mathrm{~m}$ \\
\hline & 2.3 & W7 & V71 & & $\mathrm{V} 7 \mathrm{j}$ & & $\mathrm{V} 7 \mathrm{~m}$ \\
\hline & 2.4 & W8 & V81 & & V8j & & V8m \\
\hline$\vdots$ & . & . & . & . & . & & . \\
\hline \multirow{5}{*}{$\begin{array}{l}2 \\
0 \\
\frac{0}{2} \\
\frac{0}{0} \\
0\end{array}$} & . & . & . & . & . & & . \\
\hline & . & . & . & . & . & & . \\
\hline & . & . & . & . & . & & . \\
\hline & n.n & $\mathrm{Wn}$ & Vn1 & & Vnj & & Vnm \\
\hline & Total Value & $100 \%$ & $\sum_{i=1}^{n}\left(W_{i} * V_{i 1}\right)$ & $\ldots$ & $\sum_{i=1}^{n}\left(W_{i} * V_{i j}\right)$ & $\ldots$ & $\sum_{i=1}^{n}\left(W_{1} * V_{i m}\right)$ \\
\hline
\end{tabular}

Source: Authors

Table Vi. First Level Objectives

\begin{tabular}{|l|c|c|c|c|c|}
\hline $\begin{array}{c}\text { Factors To } \\
\text { Be Assessed }\end{array}$ & 1.Costs & 2.Design & 3.Logistics & 4.Environment & Total \\
\hline 1. Costs & 5.0 & 7.0 & 6.0 & 6.0 & 24.00 \\
\hline 2. Design & 0.143 & 5.0 & 8.0 & 7.0 & 0.382 \\
\hline 3. Logistics & 0.167 & 0.125 & 5.0 & 0.320 \\
\hline 4. Environment & 0.167 & 0.143 & 0.125 & 5.0 & 0.211 \\
\hline
\end{tabular}

Source: Authors 
DESIGN METHODOLOGY FOR THE SELECTION OF THE BEST ALTERNATIVE

OF INDUSTRIAL MACHINE MAINTENANCE FOR TIME REDUCTION

Table VII. Second Level Objectives - Costs

\begin{tabular}{|c|c|c|c|c|c|c|c|c|}
\hline \multicolumn{6}{|c|}{ 1. COSTS } & \multicolumn{3}{|c|}{0.382} \\
\hline \multirow{2}{*}{ Objectives * } & \multirow{2}{*}{1.1} & \multirow{2}{*}{1.2} & \multirow{2}{*}{1.3} & \multirow{2}{*}{1.4} & \multirow{2}{*}{1.5} & TOTAL & \multirow{2}{*}{ RELATIVE WEIGHT } & \multirow{2}{*}{ ABSOLUTE WEIGHT } \\
\hline & & & & & & (LINE) & & \\
\hline 1.1 & 5 & 6 & 7 & 6 & 6 & 30 & 0.331 & 0.127 \\
\hline 1.2 & 0.167 & 5 & 6 & 6 & 7 & 24.167 & 0.267 & 0.102 \\
\hline 1.3 & 0.143 & 0.167 & 5 & 8 & 6 & 19.31 & 0.213 & 0.081 \\
\hline 1.4 & 0.167 & 0.167 & 0.130 & 5 & 6 & 11.458 & 0.127 & 0.048 \\
\hline 1.5 & 0.167 & 0.143 & 0.167 & 0.167 & 5 & 5.643 & 0.062 & 0.024 \\
\hline \multicolumn{6}{|l|}{ TOTAL } & 90.577 & 1 & 0.382 \\
\hline
\end{tabular}

* Check Table I.

Source: Authors

Table VIII. Second Level Objectives - Design

\begin{tabular}{|c|c|c|c|c|c|c|}
\hline \multicolumn{4}{|c|}{ 2. DESIGN } & \multicolumn{3}{|c|}{0.32} \\
\hline \multirow{2}{*}{ Objectives * } & \multirow{2}{*}{2.1} & \multirow{2}{*}{2.2} & \multirow{2}{*}{2.3} & TOTAL & \multirow{2}{*}{ RELATIVE WEIGHT } & \multirow{2}{*}{ ABSOLUTE WEIGHT } \\
\hline & & & & (LINE) & & \\
\hline 2.1 & 5 & 8 & 6 & 19 & 0.521 & 0.167 \\
\hline 2.2 & 0.125 & 5 & 7 & 12.125 & 0.333 & 0.106 \\
\hline 2.3 & 0.167 & 0.143 & 5 & 5.310 & 0.146 & 0.047 \\
\hline \multicolumn{4}{|l|}{ TOTAL } & 36.435 & 1 & 0.320 \\
\hline
\end{tabular}

* Check Table I

Source: Authors

Table IX. Second Level Objectives - Logistics

\begin{tabular}{|c|c|c|c|c|c|c|c|}
\hline \multicolumn{5}{|c|}{ 3. LOGISTICS } & \multicolumn{3}{|c|}{0.211} \\
\hline \multirow{2}{*}{ Objectives * } & \multirow{2}{*}{3.1} & \multirow{2}{*}{3.2} & \multirow{2}{*}{3.3} & \multirow{2}{*}{3.4} & TOTAL & \multirow{2}{*}{ RELATIVE WEIGHT } & \multirow{2}{*}{ ABSOLUTE WEIGHT } \\
\hline & & & & & (LINE) & & \\
\hline 3.1 & 5 & 6 & 9 & 6 & 26 & 0.413 & 0.087 \\
\hline 3.2 & 0.167 & 5 & 8 & 6 & 19 & 0.305 & 0.064 \\
\hline 3.3 & 0.111 & 0.125 & 5 & 7 & 12 & 0.195 & 0.041 \\
\hline 3.4 & 0.167 & 0.167 & 0.143 & 5 & 5 & 0.087 & 0.018 \\
\hline \multicolumn{5}{|l|}{ TOTAL } & 63 & 1 & 0.211 \\
\hline
\end{tabular}

* Check Table I.

Source: Authors

Table X. Second Level Objectives - Environment

\begin{tabular}{|c|c|c|c|c|c|}
\hline \multicolumn{3}{|c|}{ 4. ENVIRONMENT } & \multicolumn{3}{|c|}{0.086} \\
\hline \multirow{2}{*}{ Objectives * } & \multirow{2}{*}{4.1} & \multirow{2}{*}{4.2} & TOTAL & \multirow{2}{*}{ RELATIVE WEIGHT } & \multirow{2}{*}{ ABSOLUTE WEIGHT } \\
\hline & & & (LINE) & & \\
\hline 4.1 & 5 & 6 & 11 & 0.680 & 0.059 \\
\hline 4.2 & 0.167 & 5 & 5 & 0.320 & 0.027 \\
\hline \multicolumn{3}{|l|}{ TOTAL } & 16 & 1 & 0.086 \\
\hline
\end{tabular}

* Check Table I.

Source: Authors 


\section{Specification List}

To observe the achievement degree regarding meaningful needs, a detailed list of needs with their relevance level is presented in Table XI [9].

Table XI. List Of Needs - Metrics

\begin{tabular}{|c|l|c|}
\hline $\mathbf{N} .^{\circ}$ & \multicolumn{1}{|c|}{ NEED } & Degree \\
\hline $\mathbf{1}$ & Compact and modular replacement system. & $16.7 \%$ \\
\hline $\mathbf{2}$ & $\begin{array}{l}\text { Low investment in the system' installation } \\
\text { and setting up infrastructure. }\end{array}$ & $12.7 \%$ \\
\hline $\mathbf{3}$ & Minimal manual intervention. & $10.6 \%$ \\
\hline $\mathbf{4}$ & User-friendly and inexpensive operation. & $10.2 \%$ \\
\hline $\mathbf{5}$ & Fast assembly and dismantling. & $8.7 \%$ \\
\hline $\mathbf{6}$ & Easy and low-cost maintenance. & $8.1 \%$ \\
\hline $\mathbf{7}$ & Easy installation. & $6.4 \%$ \\
\hline $\mathbf{8}$ & Eco-friendly. & $5.9 \%$ \\
\hline $\mathbf{9}$ & Low assembly costs. & $4.8 \%$ \\
\hline $\mathbf{1 0}$ & Safe handling. & $4.7 \%$ \\
\hline $\mathbf{1 1}$ & Safe and agile displacement from storage site. & $4.1 \%$ \\
\hline $\mathbf{1 2}$ & Low noise levels. & $2.7 \%$ \\
\hline $\mathbf{1 3}$ & Affordable and easy-to-find spare parts. & $2.4 \%$ \\
\hline $\mathbf{1 4}$ & Procedures with likelihood of a repetition. & $1.8 \%$ \\
\hline & & \\
\hline
\end{tabular}

Source: Authors

\section{BRAinstorming}

The six alternatives suggested to improve enhancement opportunities regarding time reduction while die replacement process are described in this section. Fig. 2 makes reference to alternative 2 ; inside the oval, mechanical finger stops to be replaced for pneumatic finger stops can be seen.

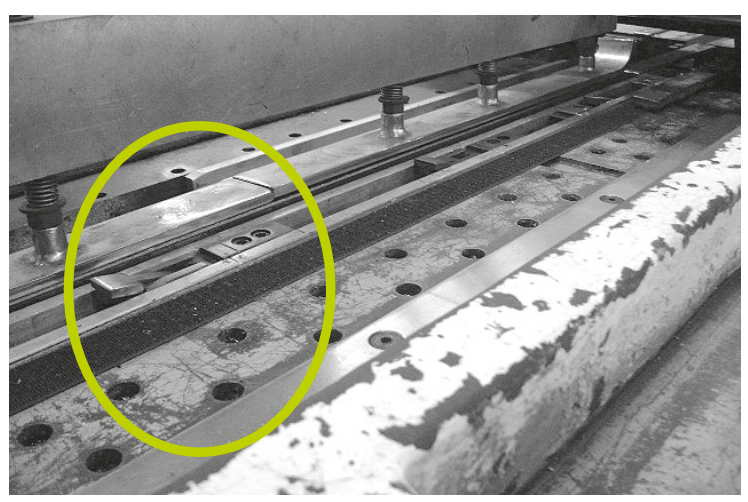

Fig. 2. Current Mechanical Finger Stops. Source: Author
Alternative 1. Addition of a selective gearbox with no pinion replacement.

Justification: Since this equipment is designed for different die-cutting process references, every time the die is replaced it is also necessary to change gear ratio to keep the same synchronism between the feeding movement and the machine's table. In addition, to reduce adjustment time, movements can become independent. For this purpose, a device can be adapted next to the existing one with a second gear set ready to be changed for the next reference; in this way, there is no need to alter the device in place but just activate the additional device.

Resources

Materials: Solenoid valve, reducer, contactor, sensor, cables, and gears.

Human: A Mechanical Technician and an Electrician are required.

Estimated Time: 5 days (80 man-hours).

Benefits: Time reduction for reference change adjustments.

\section{Alternative 2. Mechanical finger stops replacement for a pneumatic option.}

Justification: The machine works with two metal sheet references with different dimensional characteristics, for this reason, a fast guide/ finger stop positioning is required; this directed adjustment entails previously standardized positions. Fingers are in charge of propelling the sheet to be cut towards the die; for every change, these adjust, one by one, in the already delimited positions.

\section{Resources}

Materials: The machine will be equipped with pneumatic devices and position sensors that identify each reference dimensions and position the sheet automatically as demanded.

Benefits: Reduce manual operation of finger and guide adjustment.

\section{Alternative 3. Changing two lateral button control panels.}

Justification: Both lateral control panels are broken due to the impact received each time the emergency stop button is hit. Hence, it is suggested to change the control panels' location and install a protection device for them.

Resources

Materials: 2 4-button control panels.

Human: An electrician.

Estimated Time: 3 days (24 man-hours). 


\section{Selection of the Alternative}

Justification: Currently, the feeder operates manually using a lever. Every time the sheet level reduces, the operator must go to the feeder include more sheets. The system will have a manual and automatic option.

\section{Resources}

Materials: Control elements like: micro-switches, sensor, cable, terminals, selector, speed reduction rods, and limit switches.

Human: An Electrician and an assistant for sensor and PLC (Programmable Logic Controller) set up.

Estimated Time: 5 days (80 man-hours).

Benefits: Operator's full attention is addressed to the die cutting process and collection of processed strips while PLC feeds the machine.

Alternative 5. Access to improved tools.

Justification: Tightening and loosing fasteners to the die equipment is hard work. More when this task is carried through manually and with improvised tools. Hence, it is advisable for operators to use suitable tools to ease this procedure.

Resources

Materials: Air-driven fastening tools (guns), hydraulic jacks, and loading cranes.

Human: Machine operator.

Benefits: Reduce physical effort of operators and reduce die adjustments and assembly.

\section{Alternative 6. Drawing electrical and mechanical plans.}

Justification: The machine has electrical and mechanical component and the plans are missing.

Resources

Machine availability for 5 labor days to perform the drawing process.

Estimated Time: 60 man-hours (40 hrs officer y 20 hrs assistant).

Benefits: Fulfill RETIE (Technical Regulations for Electrical Installations for its acronym in Spanish, [Ministry of Mines and Energy, Colombia]) requirements and reduce inspection time during repairs.

\section{Weighted Values}

Within the first level objectives, cost is the most important. It has a difference of $6.2 \%$ in regard to design objectives, $17.2 \%$ with logistics, and $29.6 \%$ with environment. Table XII presents the six alternatives evaluated under judgment criteria (J) of people involved in the process, these values are based on operators' experience of maintenance procedures to the machine.
For the objective costs, alternative 5 received the best valuation, since by purchasing improved tools, the machine can remain without any modification. For design and logistics purposes, alternative 2 obtained the best results, since the process can become partially automatic and manual operation can be addressed to other activities; this design is simple and increases technological operation of the machine with position sensors, thus, reducing human errors. For environment, alternative 4 is the most eco-friendly because it uses an existing machine to take advantage of the process and new noise production is null.

Alternative 2 is selected as it validates the idea of producing changes to the general structure in order to simplify the arduous task of die change and adjustment. The purpose is to use pneumatic elements to speed up sheet propelling finger replacement. This alternative attained the best results in design and logistics and it requires cylinders, solenoid valves, PLC techniques, pliers, verification of compressed air conditions (vacuum, humidity, temperature), connectors, hoses, sensors, process valves, and servomotors.

One of the best advantages of these elements is the considerable reduction of the machine's volume since the aforementioned components are substantially lighter and smaller when compared to the robust cast iron structure it currently has.

\section{Conclusions}

The inclusion of design methodologies to engineering projects becomes a valuable tool to obtain strong foundations for decision making. Its relevance resides in the opportune data compilation that relates achievement and selection levels of the possible solutions to the requirements that need to be satisfied.

The use of some elements like: guide units, double-acting linear actuator, two solid guide bars for high cross-section moments and forces.

This method poses a quantitative analysis of data, a simple and practical formulation of the ideas presented, and also provides the designer with an accurate opportunity to choose the best alternative based on a set of stages and resources included within the method.

Through the use of a design methodology the targeted objective was accomplished: the identification of the best option to reduce die replacement time in the machine for the production of a $1 / 4$ gallon container lid, ring and 603 steel bottom.

The alternative for the replacement of mechanical finger stops and guides for their pneumatic versions was the option with the best weighting results (6.335). This alternative completes, in a larger proportion, the purpose set in the principal objective. 
Table XiI. Weighted Values

\begin{tabular}{|c|c|c|c|c|c|c|c|c|c|c|c|c|c|c|}
\hline \multirow{2}{*}{ Category } & \multirow{2}{*}{$\begin{array}{c}\text { Design } \\
\text { Objectives }\end{array}$} & \multirow{2}{*}{ Weight } & \multicolumn{2}{|c|}{ Altern. 1} & \multicolumn{2}{|c|}{ Altern. 2} & \multicolumn{2}{|c|}{ Altern. 3} & \multicolumn{2}{|c|}{ Altern. 4} & \multicolumn{2}{|c|}{ Altern. 5} & \multicolumn{2}{|c|}{ Altern. 6} \\
\hline & & & J & $\mathrm{W}$ & $J$ & $\mathrm{~W}$ & $\mathrm{~J}$ & $\mathrm{~W}$ & $\mathrm{~J}$ & $\mathrm{~W}$ & J & $\mathrm{W}$ & J & $\mathrm{W}$ \\
\hline \multirow{6}{*}{$\begin{array}{l}\text { Costs } \\
(38.2 \%)\end{array}$} & $\begin{array}{l}\text { 1.1 Low } \\
\text { investment in } \\
\text { the system' } \\
\text { installation } \\
\text { and setting up } \\
\text { infrastructure. }\end{array}$ & 0.127 & 7 & 0.889 & 7 & 0.889 & 5 & 0.635 & 6 & 0.762 & 7 & 0.889 & 5 & 0.635 \\
\hline & $\begin{array}{l}1.2 \text { User-friendly } \\
\text { and inexpensive } \\
\text { operation. }\end{array}$ & 0.102 & 5 & 0.51 & 7 & 0.714 & 5 & 0.51 & 5 & 0.51 & 6 & 0.612 & 5 & 0.51 \\
\hline & $\begin{array}{l}1.3 \text { Easy } \\
\text { and low-cost } \\
\text { maintenance. }\end{array}$ & 0.081 & 6 & 0.486 & 5 & 0.405 & 7 & 0.567 & 5 & 0.405 & 6 & 0.486 & 5 & 0.405 \\
\hline & $\begin{array}{l}1.4 \text { Low } \\
\text { assembly costs. }\end{array}$ & 0.048 & 6 & 0.288 & 7 & 0.336 & 7 & 0.336 & 5 & 0.24 & 7 & 0.336 & 5 & 0.24 \\
\hline & $\begin{array}{l}\text { 1.5 Affordable } \\
\text { and easy-to-find } \\
\text { spare parts. }\end{array}$ & 0.024 & 6 & 0.144 & 6 & 0.144 & 6 & 0.144 & 6 & 0.144 & 7 & 0.168 & 6 & 0.144 \\
\hline & \multicolumn{2}{|l|}{ Costs Total } & \multicolumn{2}{|c|}{2.317} & \multicolumn{2}{|c|}{2.488} & \multicolumn{2}{|c|}{2.192} & \multicolumn{2}{|c|}{2.061} & \multicolumn{2}{|c|}{2.491} & \multicolumn{2}{|c|}{1.934} \\
\hline \multirow{4}{*}{ Design (32\%) } & $\begin{array}{l}\text { 2.1 Compact } \\
\text { and modular } \\
\text { replacement } \\
\text { system. }\end{array}$ & 0.167 & 7 & 1.169 & 7 & 1.169 & 7 & 1.169 & 7 & 1.169 & 7 & 1.169 & 4 & 0.668 \\
\hline & $\begin{array}{l}\text { 2.2 Minimal } \\
\text { manual } \\
\text { intervention. }\end{array}$ & 0.106 & 5 & 0.53 & 7 & 0.742 & 5 & 0.53 & 7 & 0.742 & 5 & 0.53 & 3 & 0.318 \\
\hline & $\begin{array}{l}\text { 2.3 Safe } \\
\text { handling. }\end{array}$ & 0.047 & 6 & 0.282 & 6 & 0.282 & 6 & 0.282 & 5 & 0.235 & 7 & 0.329 & 4 & 0.188 \\
\hline & \multicolumn{2}{|l|}{ Design Total } & \multicolumn{2}{|c|}{1.981} & \multicolumn{2}{|c|}{2.193} & \multicolumn{2}{|c|}{1.981} & \multicolumn{2}{|c|}{2.146} & \multicolumn{2}{|c|}{2.028} & \multicolumn{2}{|c|}{1.174} \\
\hline \multirow{5}{*}{$\begin{array}{l}\text { Logistics } \\
(21.1 \%)\end{array}$} & $\begin{array}{l}\text { 3.1 Fast } \\
\text { assembly and } \\
\text { dismanteling. }\end{array}$ & 0.087 & 5 & 0.435 & 7 & 0.609 & 7 & 0.609 & 5 & 0.435 & 6 & 0.522 & 2 & 0.174 \\
\hline & $\begin{array}{l}3.2 \text { Easy } \\
\text { installation. }\end{array}$ & 0.064 & 5 & 0.32 & 5 & 0.32 & 5 & 0.32 & 5 & 0.32 & 5 & 0.32 & 4 & 0.256 \\
\hline & $\begin{array}{l}3.3 \text { Safe } \\
\text { and agile } \\
\text { displacement } \\
\text { from storage } \\
\text { site. }\end{array}$ & 0.041 & 5 & 0.205 & 5 & 0.205 & 5 & 0.205 & 7 & 0.287 & 7 & 0.287 & 5 & 0.205 \\
\hline & $\begin{array}{l}\text { 3.4 Procedures } \\
\text { with likelihood } \\
\text { of a repetition. }\end{array}$ & 0.018 & 7 & 0.126 & 5 & 0.09 & 5 & 0.09 & 6 & 0.108 & 5 & 0.09 & 4 & 0.072 \\
\hline & \multicolumn{2}{|l|}{ Logistics Total } & \multicolumn{2}{|c|}{1.086} & \multicolumn{2}{|c|}{1.224} & \multicolumn{2}{|c|}{1.224} & \multicolumn{2}{|c|}{1.15} & & 1.219 & & .707 \\
\hline & 4.1 Eco-friendly. & 0.059 & 5 & 0.295 & 5 & 0.295 & 5 & 0.295 & 5 & 0.295 & 5 & 0.295 & 1 & 0.059 \\
\hline $\begin{array}{c}\text { Environment } \\
(8,6 \%)\end{array}$ & $\begin{array}{l}4.2 \text { Low noise } \\
\text { levels. }\end{array}$ & 0.027 & 5 & 0.135 & 5 & 0.135 & 5 & 0.135 & 6 & 0.162 & 5 & 0.135 & 1 & 0.027 \\
\hline & Environment Tc & & & 0.43 & & 0.43 & & 0.43 & & .457 & & 0.43 & & .086 \\
\hline & Total & & & 5.814 & & 3.335 & & 5.827 & & 5.814 & & 6.168 & & .901 \\
\hline
\end{tabular}

J: Judgment W: Weighting

Source: Source 


\section{DESIGN METHODOLOGY FOR THE SELECTION OF THE BEST ALTERNATIVE \\ OF INDUSTRIAL MACHINE MAINTENANCE FOR TIME REDUCTION}

The company can implement this technology to develop enhancements in different fields of work; with this study, it was validated for maintenance first, however, as it becomes more used within permanent enhancement projects in the company, the advantages can become more evident.

The support of the University in this process and the inclusion of the operators allowed an increase in the sense of belonging of the workers as they manifested their intention of presenting enhancement proposals to keep implementing this type of methodology in different areas.

\section{REFERENCES}

[1] C. H. Glock, "The machine breakdown paradox: How random shifts in the production rate may increase company profits," Comput. Ind. Eng., vol. 66, no. 4, pp. 11711176, Dec. 2013. DOI: 10.1016/j.cie.2013.07.018

[2] R. L. Norton, Diseño de Maquinaria: Síntesis y análisis de máquinas y mecanismos, 1 st ed., vol. 1. Mexico: McGrawHill, 1992, p.7
[3] M. M. García, B. V. Cloquell, and T. Gómez, Metodología del Diseño Industrial. España: Editorial de la UPV Camino de Vera, 2002, p. 141

[4] W. Velilla Díaz, D. Montero Álvarez, O. Pérez Ariza, and R. Álvarez Barreto, "Metodología de diseño conceptual para la selección de un sistema manipulador de tambores para camiones de carga," Prospectiva, vol. 8, no. 1, pp. 53-62, 2010.

[5] W. Velilla, L. Amórtegui, D. Montero, O. Oviedo, and Ó. Pérez, "Diseño de un sistema semiautomático para la extracción de gel de aloe vera; análisis integral del costo del ciclo de vida del equipo," INGE CUC, vol. 9, no. 1, pp. 99-113, Jun. 2013.

[6] T. Curry, "A theoretical basis for recommending the use of design methodologies as teaching strategies in the design studio," Des. Stud., vol. 35, no. 6, pp. 632-646, Nov. 2014. DOI: $10.1016 /$ j.destud.2014.04.003

[7] J. I. García, Fundamentos del Diseño Mecánico. Colom bia: Programa Editorial Universidad del Valle, 2004, p 11.

[8] D. R Anderson, D. J. Sweeney, A. W. Thomas. Métodos Cuantitativos para los Negocios. México. Editorial Thomson, 2004, p. 774

[9] K. T. Ulrich. Diseño y Desarrollo de Producto. México. McGraw-Hill Interamericana, 2009, pp. 83 